\title{
Use of Amazon Fruits Barks as Source of Nutrients
}

\author{
I. F. Montero ${ }^{1,2}$, S. A. M. Saravia ${ }^{3}$, R. A. Santos ${ }^{4}$, J. A. F. Marcia ${ }^{5}$, S. M. Silva ${ }^{6} \&$ E. A. Chagas ${ }^{2,7}$ \\ ${ }^{1}$ Polytechnic School, Department of Organic and Inorganic Chemistry, University of Extremadura, Cáceres, Spain \\ ${ }^{2}$ Postgraduate Program in Biodiversity and Biotecnology, State Coordination of Roraima, Federal University of \\ Roraima, Campus Paricarana, Boa Vista, RR, Brazil \\ ${ }^{3}$ Faculty of Earth Sciences and Conservation, National University of Agriculture, Catacamas, Olancho, Honduras \\ ${ }^{4}$ Department of Food Science, Louisiana State University, USA \\ ${ }^{5}$ Faculty of Technological Sciences, National University of Agriculture, Catacamas, Olancho, Honduras \\ ${ }^{6}$ Graduate Program in Health Sciences, Federal University of Roraima, Campus Paricarana, Boa Vista, RR, \\ Brazil \\ ${ }^{7}$ Brazilian Agricultural Research Corporation (Embrapa), Boa Vista, Brazil \\ Correspondence: I. M. Fernández, Polytechnic School, Department of Organic and Inorganic Chemistry, \\ University of Extremadura, Avenida de la Universidad s/n, Cáceres, Spain. E-mail: ismonterof@unex.es
}

Received: April 7, 2019 Accepted: January 30, $2020 \quad$ Online Published: February 15, 2020

doi:10.5539/jas.v12n3p233 URL: https://doi.org/10.5539/jas.v12n3p233

\begin{abstract}
The barks of fruits are usually discarded as organic waste; a valuable source of nutrients is obtained are used as a starting source in the preparation of functional foods. In this work, the physicochemical properties ( $\mathrm{pH}$, titrable acidity and soluble solids), mineral and bromatological analysis of nine Amazonian fruits were studied: abiu, acerola, araçá, bacupari, biribá, camu-camu, fruta-do-conde, araçá and taperebá. The most acidic values stand out for the different fruits, with the exception of the abiu bark $(\mathrm{pH}=4.7)$. As for its nutritional contribution, it

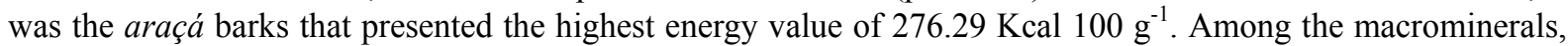
the potassium concentration stands out, being the highest concentration for the graviola bark, $521.04 \mathrm{mg}^{100 \mathrm{~g} \mathrm{~g}^{-1}}$ followed by magnesium, where the concentration in the biribá was $64.21 \mathrm{mg} 100 \mathrm{~g} \mathrm{~g}^{-1}$. On the other hand, the husks are rich in micronutrients, highlighting the concentration of zinc in the bark of araçá, $12.23 \mathrm{mg} 100 \mathrm{~g} \mathrm{~g}^{-1}$ and manganese in the bark of abiu, $6.84 \mathrm{mg} 100 \mathrm{~g}^{-1}$. The Pearson correlation coefficient presented a highly significant correlation for Fe-Al (0.96), P-Fe (0.94) and Fe-Zn (0.89). O bligpot of principal components (PCA) explains $56 \%$ of the cases, being the minerals $\mathrm{Mg}, \mathrm{Na}, \mathrm{Co}, \mathrm{K}, \mathrm{S}$ and $\mathrm{Ca}$ highly associated for the graviola and Reywarín: minerals, sustainability, bromatology, foods
\end{abstract}

\section{Introduction}

Brazil produces about 140 million tons of food per year, being the largest exporters of agricultural products, but at the same time there are problems with waste (Godim et al., 2005). From the foods wasted, 32 million tons are fruit (Maia et al., 2007). Among those industrial waste we have the part of the fruit husks, rich in nutrients, they are source of compounds with antioxidant activity (Montero et al., 2018). In addition, they have minerals both in high concentrations and in moth concentrations, as well as source of vitamins.

In Brazil, an important amount of waste is generated in the processing of fruits, mainly composed of husks, barks and bagasse, whose common destination is being discarded or destined for the production of fertilizers, occupying a total volume of $40 \%$ of processed fruits (Silva, 2014; Ajila et al., 2007). Among the main industrial residues in Brazil are the residues of the wine industry with a high concentration of antioxidants (Rubilar et al., 2007), in fruits, for example the tomato (Solanum lycopersicum) (Correia et al., 2004), the goiaba (Psidium guajava) (Melo \& Vilela, 2005) and malted barley (Hordeum vulgare) in the beer industry (Santos, 2005).

Due to the nutritional importance of fruit residues, in this study, the fruits of nine fruits were evaluated in northern Amazonia: abiu (Pouteria caimito), acerola (Malpighia emarginata), araçá (Psidium cattleianum), bacupari (Rheedia gardneriana), biribá (Rollinia mucosa), camu-camu (Myrciaria dubia), fruta-do-conde (Annona squamosa), graviola (Annona muricata) and taperebá (Spondias mombin L.), the nutritional value, 
macro and microminerals, as well as the physico-chemical properties ( $\mathrm{pH}$, titratable acidity, total soluble solids) and reducing and non-reducing sugars in order to be considered the use of the residues for the production of bioproducts.

\section{Materials and Methods}

\subsection{Preparation of Samples}

Samples (Table 1) were collected from fruit markets and producers in Roraima state, Brazil. Then, the collected fruits were taken to the Laboratory of the Agronomic Research Center, at the Agricultural Sciences Center, Cauamé campus, Federal University of Roraima, fruits with good appearance were selected, washed previously with distilled water and then with hypochlorite solution of sodium chloride and finally with distilled water again.

Table 1. Names and families of fruits cultivated in the Northern Amazon studied in this work

\begin{tabular}{lll}
\hline Scientific name & Family & Name in Brazil \\
\hline Pouteria caimito & Sapotaceae & Abiu \\
Malpighia emarginata & Malpighiaceae & Acerola \\
Psidium cattleianum & Myrtaceae & Araçá \\
Rheedia gardneriana & Clusiaceae & Bacupari \\
Rollinia mucosa & Annonaceae & Biribá \\
Myrciaria dúbia (Krunth) Mc Vaugh, Myrtaceae & Myrtaceae & Camu-camu \\
Annona squamosa & Annonaceae & Fruta-do-conde \\
Annona muricata & Annonaceae & Graviola \\
Spondias mombin L. & Anacardiaceae & Taperebá \\
\hline
\end{tabular}

The fruits were pulped, weighed and frozen in an ultra-freezer at $-80{ }^{\circ} \mathrm{C}$ for further lyophilization in Liotop L101 lyophilizer for 48 hours, until complete drying. After drying, the samples were ground in a knife mill and sieved between 30-40 Mesh, and stored in hermetically sealed sachets and protected from light to perform nutritional.

\subsection{Physical Chemistry Parameters: pH, Titratable Acidity and Soluble Solids}

The $\mathrm{pH}$ was determined by potentiometry using a $\mathrm{pH}$ meter previously calibrated. The titratable acidity (AT) was determined by diluting 5 grams of lyophilized material, dissolved in $100 \mathrm{~mL}$ of distilled water with $\mathrm{NaOH}$ titration $(0.1 \mathrm{M})$ until the phenolphthalein was turned $(\mathrm{pH} 8.1)$ and the results expressed as $\mathrm{g}$ citric acid in $100 \mathrm{~g}$ of pulp. Soluble solids (SS) were determined by refractometry with the fresh samples, expressed in ${ }^{\circ}$ Brix and lastly, the SS/TA ratio were determined by the ratio between soluble solids content and titratable acidity (IAL, 2008).

\subsection{Nutritional Analysis}

The physical parameters evaluated to determine the nutritional composition were the percentage of moisture and ash. The other nutritional parameters evaluated were the determination of total proteins, lipids and carbohydrates, to determine the total energy content (IAL, 2008).

\subsubsection{Determination of Humidity}

To determine moisture, $5 \mathrm{~g}$ of fresh samples were placed in porcelain capsules for 6 hours at $105^{\circ} \mathrm{C}$ to constant mass, and then cooled in desiccator to room temperature (IAL, 2008).

$$
\text { Humidity }(\mathrm{g} / 100 \mathrm{~g})=\left[\left(\mathrm{P}^{\prime}-\mathrm{P}^{\prime \prime}\right) /\left(\mathrm{P}^{\prime}-\mathrm{P}\right)\right] \times 100
$$

Where, $\mathrm{P}=$ weight of porcelain capsule $(\mathrm{g}) ; \mathrm{P}$ ' = weight of the porcelain capsule + fresh sample $(\mathrm{g}) ; \mathrm{P} "=$ weight of the capsule + sample after the oven (g).

\subsubsection{Determination of Ashes}

To determine the ash in the samples, the methodology proposed for the food analysis (IAL, 2008) with modifications was used, where 5 grams of the lyophilized samples were weighed. These were placed in preheated porcelain crucibles in an oven at $110{ }^{\circ} \mathrm{C}$ for one hour, to remove moisture, and cool them in a desiccator to room temperature. The samples were incinerated at $600{ }^{\circ} \mathrm{C}$ in a FDG 3P-S EDG muffle for 16 hours, after which the samples were left in the desiccator until reaching room temperature.

$$
\% \text { ashes }=(\mathrm{N} \times 100) / \mathrm{M}
$$

Where, $\mathrm{N}=$ mass in grams of ash and $\mathrm{M}=$ mass of the sample in grams. 


\subsubsection{Determination of Total Proteins}

Protein determination is performed from the total nitrogen analysis by Kjeldahl distillation, in which the existing organic matter is transformed into ammonia. The nitrogen content of the different proteins is approximately $16 \%$, which introduces the empirical factor of 5.75 (conversion factor for vegetable protein), this will transform the number of grams of nitrogen, found with the number of grams of protein (IAL, 2008).

$$
\% \text { proteins }=\% \mathrm{~N} \times 5.75
$$

\subsubsection{Determination of Lipids}

To determine the total amount of lipids, $20 \mathrm{~g}$ of each sample was weighed, and placed in the Soxhlet extractor apparatus with hexane as the solvent for six hours. The solvent was recovered in a rotary evaporator (IAL, 2008).

$$
\% \text { lipids }=(\mathrm{N} \times 100) \times \mathrm{m}
$$

Where, $\mathrm{N}=$ mass in grams of lipids and $\mathrm{M}=$ mass of the sample in grams.

\subsubsection{Determination of Carbohydrates}

The carbohydrate content is achieved by the difference of the value 100 subtracted from the sum of the already obtained values of moisture, ashes, lipids and proteins.

$$
\text { Carbohydrates }=100-(\% \text { moisture }+\% \text { ash }+\% \text { lipids }+\% \text { proteins })
$$

\subsubsection{Energetic Value}

In order to quantify the energy value, it was necessary to use the protein (P), lipid (L) and carbohydrate (C)

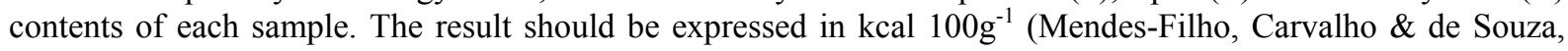
2014).

$$
\text { Energy value }(\mathrm{kcal} / 100 \mathrm{~g})=(\mathrm{P} \times 4)+(\mathrm{L} \times 9)+(\mathrm{C} \times 4)
$$

Where, $\mathrm{P}=$ value of protein (\%), $\mathrm{L}=$ lipid value $(\%), \mathrm{C}=$ carbohydrate value $(\%), 4$ = conversion factor in $\mathrm{kcal}$ determined in calorimetric pump for proteins and carbohydrates and $9=$ conversion factor in kcal determined in a calorimetric pump for lipids.

\subsection{Mineralogical Analysis}

The extraction of the minerals into the epidermis was done according to the methodology described by (Embrapa, 2009) in which the perchloric nitric digestion (3:1) was used in TECNAL model TE 0079 digester block, washed with distilled water up to $25 \mathrm{~mL}$ for subsequent analysis.

Calcium $(\mathrm{Ca})$, magnesium $(\mathrm{Mg})$, iron $(\mathrm{Fe})$, copper $(\mathrm{Cu})$, zinc $(\mathrm{Zn})$, manganese $(\mathrm{Mn})$ and aluminum $(\mathrm{Al})$ were determined by Flame Atomic Absorption Spectrophotometry (FAAS) Shimadzu AA-7000, coupled with ASC-7000 auto sample. Calibration was performed with standard solutions prepared from commercial standards of $1000 \mathrm{mg} \mathrm{L}^{-1}$ Qhemis High Purity PACU 1000-0125, according to the specific conditions of each element (Table 2). 
Table 2. Analytical parameters of calibration

\begin{tabular}{|c|c|c|c|c|c|}
\hline Element & Technique & $(\lambda) \mathbf{n m}$ & Correlation coefficient $\left(r^{2}\right)$ & $\operatorname{LOD}\left(\mathrm{mg} \mathrm{L} \mathrm{L}^{-1}\right)$ & LOQ (mg L $\left.{ }^{-1}\right)$ \\
\hline $\mathrm{Ca}$ & FAAS & 422.70 & 0.999 & 0.481 & 2.004 \\
\hline $\mathrm{Mg}$ & FAAS & 285.21 & 0.997 & 0.571 & 1.992 \\
\hline $\mathrm{P}$ & UV-Vis spectroscopy & 660.00 & 0.999 & 0.113 & 1.773 \\
\hline K & AES & 766.50 & 0.993 & 0.571 & 1.754 \\
\hline $\mathrm{S}$ & UV-Vis spectroscopy & 420.00 & 0.998 & 0.074 & 0.897 \\
\hline $\mathrm{Fe}$ & FAAS & 248.33 & 0.996 & 0.002 & 0,011 \\
\hline $\mathrm{Zn}$ & FAAS & 213.80 & 0.991 & 0.002 & 0.071 \\
\hline $\mathrm{Mn}$ & FAAS & 279.48 & 0.999 & 0.001 & 0.603 \\
\hline $\mathrm{Cu}$ & FAAS & 324.75 & 0.997 & 0.003 & 0.010 \\
\hline $\mathrm{Na}$ & AES & 589.0 & 0.999 & 0.098 & 1.103 \\
\hline $\mathrm{Al}$ & FAAS & 309.3 & 0.998 & 0.0008 & 0.078 \\
\hline B & UV-Vis spectroscopy & 420.00 & 0.999 & 0.089 & 0.123 \\
\hline Co & FAAS & 240.73 & 0.997 & 0.0005 & 0.0008 \\
\hline
\end{tabular}

Note. FAAS = Flame Atomic Absorption Spectroscopy. AES = Flame Atomic emission Spectroscopy. LOD $=$ detection limit. LOQ = Quantification limit.

As the ionization suppressor for the $\mathrm{Ca}$ and $\mathrm{Mg}$ elements, $0.1 \%$ of the lithium oxide solution $\left(\mathrm{La}_{2} \mathrm{O}\right)$ was used. In the case of sodium $(\mathrm{Na})$, it was determined in the same equipment, but in atomic emission mode. As for potassium (K), it was determined by means of flame photometry on the Digimed Flame Photometer DH-62, calibrated using a Digimed standard solution whose concentration range was 2-100 $\mathrm{mg} \mathrm{L}^{-1}$.

For the determination of the phosphorus (P), boron (B) and sulfur (S) elements, the ultraviolet molecular absorption spectrophotometry technique was used using a SHIMADZU UV-1800 model, according to the (Embrapa, 2009), by formation of the colorimetric reaction with ammonium molybdate $\left(\left(\mathrm{NH}_{4}\right)_{2} \mathrm{MoO}_{4}\right)$. In the case of $P$, blue complex formed, where the readings were made at $\lambda=660 \mathrm{~nm}$; in the case of $B$ complex was formed with Azometine-H of yellow color and absorbs light at $\lambda=460 \mathrm{~nm}$; and for the sulfur was precipitated with $\mathrm{BaCl}_{2}$, calibrating with potassium sulphate, at $\lambda=420 \mathrm{~nm}$.

Nitrogen determination was carried out by the distillation method followed by titration (Kjeldahl), where the ammonium ion produced in the digestion with sulfuric acid $\left(\mathrm{H}_{2} \mathrm{SO}_{4}\right)$ is distilled in strongly alkaline medium in the Kjeldahl distiller model TECNAL TE-036/1, collected $(0.01 \%)$ and methyl red $(0.04 \%)$ and titrated with $0.01 \mathrm{~mol} \mathrm{~L}^{-1} \mathrm{HCl}$ solution were added in $2 \%$ boric acid solution with a mixture of green bromocresol $(0.01 \%)$ and methyl (Embrapa, 2009).

$$
\% \mathrm{~N} \text { total }=(\mathrm{V} \times 0.028) / \mathrm{m}
$$

Where, $\mathrm{V}=$ difference in the titration volume of the sample blank; $\mathrm{m}=$ mass of the sample in grams; and the value $0.028=$ milliequivalents grams of nitrogen multiplied by the concentration.

\subsection{Statistical Analysis}

Correlations between the amounts of the different minerals in the epidermis of the fruit were evaluated using the Pearson statistical test using INFOSTAT (Rienzo et al., 2016) for significance levels of 5\%, 1\% and 0.1\% respectively, as well as the principal component analyzes (PCA) and Hierarchical component analysis (HCA).

\section{Results and Discussion}

\subsection{Physicochemical Characterization}

The parameters of physicochemical analysis studied in this work ( $\mathrm{pH}$, titratable acidity (TA), total soluble solids (SS) and SS/TA ratio) its serve to characterize the quality of the fruit, to potentiate or as a functional food (Canuto et al., 2010). In Table 3, the results of the physicochemical parameters for the different fruits are presented, with their standard deviation made for three repetitions using the value of the t-student for the $95 \%$ probability. 
Table 3. Physicochemical parameters for the skin of different fruits

\begin{tabular}{lllll}
\hline Fruit & $\mathbf{p H}$ & TA $\left(\mathbf{g}\right.$ citric acid $\left.\mathbf{1 0 0} \mathbf{g}^{-1}\right)$ & SS $\left({ }^{\mathbf{0}}\right.$ Brix) & SS/TA \\
\hline Abiu & $4.7 \pm 0.1$ & $5.6 \pm 0.1$ & $2.7 \pm 0.2$ & $0.48 \pm 0.1$ \\
Acerola & $2.1 \pm 0.2$ & $1.2 \pm 0.1$ & $2.9 \pm 0.1$ & $2.41 \pm 0.1$ \\
Araçá & $4.3 \pm 0.1$ & $0.4 \pm 0.1$ & $4.5 \pm 0.2$ & $11.25 \pm 0.2$ \\
Bacuparí & $3.1 \pm 0.2$ & $1.9 \pm 0.2$ & $7.1 \pm 0.1$ & $3.74 \pm 0.2$ \\
Biribá & $3.0 \pm 0.2$ & $2.4 \pm 0.2$ & $8.1 \pm 0.1$ & $3.38 \pm 0.1$ \\
Camu camu & $2.4 \pm 0.1$ & $1.7 \pm 0.2$ & $4.3 \pm 0.2$ & $2.52 \pm 0.2$ \\
Fruta-do-conde & $2.9 \pm 0.1$ & $2.7 \pm 0.1$ & $8.7 \pm 0.1$ & $3.22 \pm 0.1$ \\
Graviola & $3.1 \pm 0.1$ & $2.1 \pm 0.1$ & $8.4 \pm 0.1$ & $4.0 \pm 0.1$ \\
Taperebá & $2.7 \pm 0.2$ & $1.7 \pm 0.2$ & $5.7 \pm 0.1$ & $3.35 \pm 0.1$ \\
\hline
\end{tabular}

The $\mathrm{pH}$ value for the different fruits studied ranges from 2.1 for acerola bark, reaching 4.7 for the bark of the abiu. The titratable acidity expressed in $\mathrm{mg}$ of citric acid $100 \mathrm{~g}^{-1}$ presents values of $0.4 \pm 0.1$ for the araçá bark up to $5.6 \pm 0.1$ for the abiu. This parameter is important, since it indicates the maturity of the fruit, measuring the titratable hydrogens contained in the fruits of all the acids that constitute it until they are neutralized at a fixed $\mathrm{pH}$ value. It is expressed as the equivalent of citric acid since it is the predominant acid in fruits and according to Fernández et al. (2006), this parameter can not be less than 0.4 . The value of the SS expressed in ${ }^{\circ}$ Brix varies between $2.7 \pm 0.2$ for the abiu, reaching the value of $8.7 \pm 0.1$ for the fruta-do-conde. Finally, the SS/TA ratio gave values between 0.48 for the abiu to values of 11.25 for the araçá. This parameter relates the quality of the fruit in terms of maturity and flavor (M. I. F. Chitarra \& A. B. Chitarra, 2005).

There are few data in the literature about the physicochemical parameters in the skin of these Amazonian fruits, being limited to the study of pulps. In the case of camu-camu, studies carried out by Maeda et al. (2006), the physicochemical parameters for the pulp of the camu-camu, being the $\mathrm{pH}$ of the pulp of 2.64 slightly higher than that of the bark, the solids solids also, with $6.20^{\circ}$ Brix and the titratable acidity is also higher for the pulp ( $3.40 \mathrm{~g}$ $100 \mathrm{~g}^{-1}$ of citric acid). In the case of the fruit-do-count, Bonfim et al. (2014) study said fruit in different stages of fruit maturity, finding values in the mature state of soluble solids between (17.25-20.22 $\left.{ }^{\circ} \mathrm{Brix}\right)$ values higher than those found for the skin and potential acidity value between $(0.18-0.23 \%)$ also higher than those found for the skin in this work.

There is a work developed by Carlone et al. (2016), where they prepare a flour of bacuparí made from the pulp and the barks finding $\mathrm{pH}$ values of 3.18 similar to those determined in this work and titulable acidity of $7.82 \mathrm{~g}$ $100 \mathrm{~g}^{-1}$ of citric acid, greater than those presented here, since in this work not only the skin of the fruit is being evaluated, but also the pulp is being evaluated.

For the graviola, if studies were found that evaluate the bark of the same, made by Silva (2016), where the $\mathrm{pH}$ value determined is approximately one unit lower than the one determined in this work and for the titratable acidity, it finds a value of $3.70 \mathrm{~g} 100 \mathrm{~g}^{-1}$ of citric acid, somewhat higher than what we determine, since acidity influences the degree of ripeness of the fruit. On the other hand, Sacramento et al. (2003), study the pulp of the graviola, where the determined value of $\mathrm{pH}$ is 3.44 being approximate to the one we determined in this work for

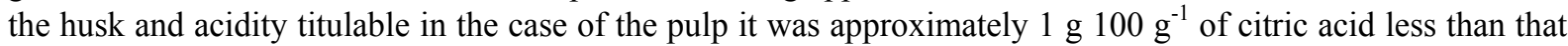
determined in the bark.

In the case of taperebá, no results have been found for physicochemical analysis in the bark, only for the pulp being determined by Freitas (2017), $\mathrm{pH}$ values for the pulp between 2.60-2.95, being within the range of $\mathrm{pH}$

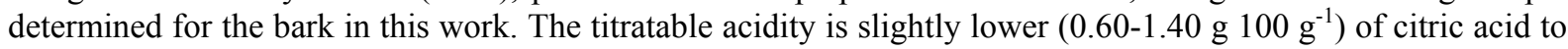
the one determined for the skin and the soluble solids in the pulp are slightly larger (9.96-11.30).

The araçá presents studies for the pulp, whose $\mathrm{pH}$ values vary between 3.0-4.0, titratable acidity between

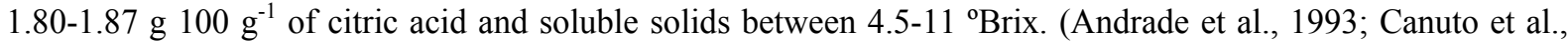
2010). The $\mathrm{pH}$ values determined for the pulps are close but slightly lower than those of the bark of the fruits evaluated in this work, the titratable acidity is much lower for the skin and in the case of the SS, these are close to the determined by Canuto et al. (2010) for the pulp.

In the case of the abiu, the $\mathrm{pH}$ of the skin is close to that of the pulp determined by Canuto et al. (2010), who obtains a $\mathrm{pH}$ value of 5.0 The titratable acidity is lower for the pulps than for the barks but with very close value

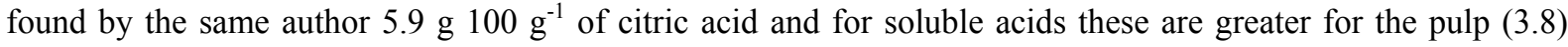
according to the same author as for the skin. For acerola Godoy et al. (2008) and Canuto et al. (2010), the pH value for pulp (2.8-3.4) is slightly higher than that found for the skin in this work, the potential acidity for the 
skin is within the range determined by these authors $(0.92-1.90) \mathrm{g} 100 \mathrm{~g}^{-1}$ of citric acid and the soluble solids for the bark of this work are lower than those found by the previous authors for the pulp of these fruits with values of (3.5-8.24) ${ }^{\circ}$ Brix.

\subsection{Bromatological Analysis From Bark of Amazon Fruits}

Table 4 presents the nutritional analysis values for the bark of the different Amazonian fruits studied.

Of all the parameters that make up the bromatological analysis, moisture is the majority in the barks of the fruits studied compared to the other parameters, ranging from $32.12 \%$ for yellow araçá bark to $88.99 \%$ for acerola. The content of ashes in the fruit exocarp does not reach $1 \%$, with the lowest concentration for the taperebá with $0.24 \%$ and $0.89 \%$ for the fruta-do-conde.

The content of lipids in the husk is low, in relation to other parts of the fruit, being in lower concentration for the taperebá with a percentage of $0.12 \%$ and the highest concentration for the bacupari with $1.41 \%$. The carbohydrate content varies according to the fruit in a high percentage range, determining a percentage of $9.62 \%$ for the biribá to $65.58 \%$ for the araçá.

The proteins are another one of the nutrients that are in low concentration in the bark of the fruits, being only in concentration of $0.04 \%$ for the acerola, reaching values of $0.41 \%$ for the abiu. The energy contribution of the

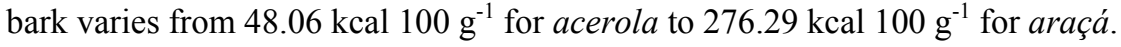

Table 4. Nutritional composition in bark of Amazonian fruit

\begin{tabular}{|c|c|c|c|c|c|c|}
\hline \multirow{2}{*}{ Fruit } & \multicolumn{6}{|c|}{ Nutritional Contribution } \\
\hline & Moisture & Ashes & Lipids & Carbohydrates & Proteins & Energetic Value \\
\hline & 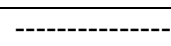 & - & --------\% - & --------------------". & 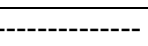 & --- Kcal $100 \mathrm{~g}^{-1}$--- \\
\hline Abiu & $82.49 \pm 0.09$ & $0.41 \pm 0.02$ & $1.27 \pm 0.02$ & $15.42 \pm 0.01$ & $0.41 \pm 0.02$ & $74.75 \pm 0.01$ \\
\hline Acerola & $88.89 \pm 0.05$ & $0.27 \pm 0.03$ & $0.94 \pm 0.02$ & $9.86 \pm 0.01$ & $0.04 \pm 0.00$ & $48.06 \pm 0.01$ \\
\hline Araçá & $32.12 \pm 0.12$ & $0.52 \pm 0.09$ & $1.37 \pm 0.13$ & $65.58 \pm 0.01$ & $0.41 \pm 0.02$ & $276.29 \pm 0.01$ \\
\hline Bacupari & $84.37 \pm 0.21$ & $0.38 \pm 0.11$ & $1.41 \pm 0.03$ & $13.52 \pm 0.02$ & $0.32 \pm 0.02$ & $68.05 \pm 0.01$ \\
\hline Biribá & $88.32 \pm 0.07$ & $0.77 \pm 0.17$ & $1.12 \pm 0.06$ & $9.62 \pm 0.02$ & $0.17 \pm 0.02$ & $49.24 \pm 0.02$ \\
\hline Сати-сати & $83.12 \pm 0.09$ & $0.31 \pm 0.09$ & $1.12 \pm 0.04$ & $15.37 \pm 0.01$ & $0.08 \pm 0.00$ & $71.88 \pm 0.01$ \\
\hline Fruta-do-conde & $85.43 \pm 0.02$ & $0.89 \pm 0.03$ & $1.27 \pm 0.01$ & $12.30 \pm 0.02$ & $0.11 \pm 0.01$ & $61.07 \pm 0.03$ \\
\hline Graviola & $74.16 \pm 0.08$ & $0.72 \pm 0.04$ & $1.04 \pm 0.04$ & $23.91 \pm 0.02$ & $0.17 \pm 0.03$ & $105.68 \pm 0.05$ \\
\hline Taperebá & $73.21 \pm 0.13$ & $0.24 \pm 0.12$ & $0.12 \pm 0.04$ & $26.32 \pm 0.02$ & $0.11 \pm 0.01$ & $106.80 \pm 0.02$ \\
\hline
\end{tabular}

Note. Analyzes performed in triplicate and using as a standard deviation the value of the t-student for $95 \%$.

\subsection{Mineral Analysis}

In the Table 5 and the Table 6 , the values of macronutrients and micronutrients are presented for the different barks studied. Among the macronutrients detected in the barks of different fruits, potassium stands out as the

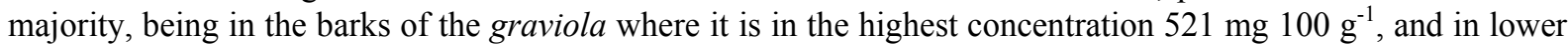

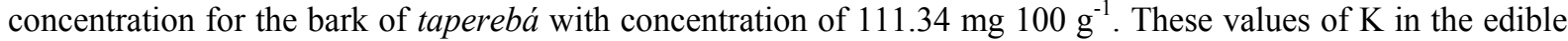
fraction are in agreement with those established by Almeida et al. (2009), where they establish that K levels in the edible fraction of fruits ranges between $143.67-790.11 \mathrm{mg} 100 \mathrm{~g}^{-1}$. Elcinto (2000), notes that this element is found in high concentrations in fresh fruits and vegetables, especially in the bark and stem of edible fruits. Its importance in the organism is in the maintenance of the hydroelectric balance with sodium, the concentrations of these elements being regulated inside and outside the cell Cuppari and Bazanelli (2010). The concentrations of sodium in the fruits studied are lower than the potassium concentrations, with the highest concentration for the

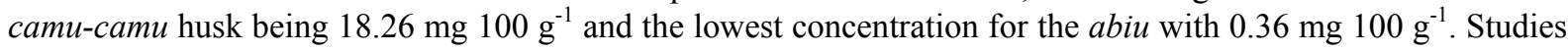
of this mineral in plants of the Annonaceae family, determined Na concentration for the graviola of $3.11 \mathrm{mg} 100$

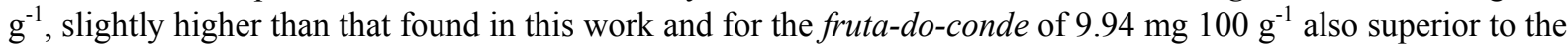
one found in this work (Bramont et al., 2008).

Unlike what happens with potassium, calcium in the barks of the fruit is of great importance, since it is the element that gives it firmness, being associated with high levels of calcium to a good quality of the fruit (Johnston et al., 2002; Poovaiah et al., 1988). In this study, Ca is the second element in abundance after K, with the highest concentration in the skin of camu-camu with $52.21 \mathrm{mg} 100 \mathrm{~g}^{-1}$ and the lowest concentration for abiu with $22.11 \mathrm{mg} 100 \mathrm{~g}^{-1}$. The next element in abundance in the fruits studied is the $\mathrm{Mg}$, being the skin of biribá

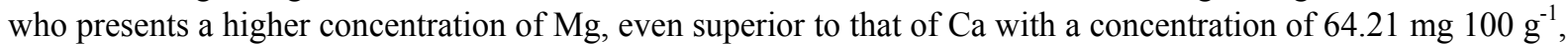


with a lower concentration of the skin of the abiu again with $13.21 \mathrm{mg} 100 \mathrm{~g}^{-1}$. Berto et al. (2015) determined

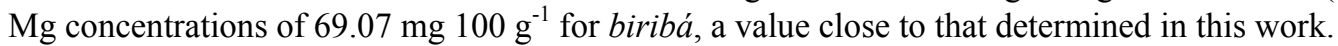

The importance of phosphorus in the organism lies in its involvement in metabolic functions such as the synthesis of ATP, synthesis of carbohydrates, nucleic acids and coenzymes (Epstein \& Bloom, 2006), being found in the body between $0.8-1.1 \%$ (Monteiro \& Vannucchi , 2010). The highest concentration of phosphorus was in araçá with $43.47 \mathrm{mg} 100 \mathrm{~g} \mathrm{~g}^{-1}$ and the lowest concentration of abiu husk with $4.3 \mathrm{mg} 100 \mathrm{~g} \mathrm{~g}^{-1}$. The concentration of minerals in Biribá fruits was studied by Berto et al., (2015) who determined P concentrations in this fruit of $25.32 \mathrm{mg} 100 \mathrm{~g}^{-1}$, close to the value found in this work.

Sulfur is within the macrominerals, found in a wide range of values for the fruits studied, from $3.14 \mathrm{mg} 100 \mathrm{~g} \mathrm{~g}^{-1}$ for the bacuparí, to $37.22 \mathrm{mg} 100 \mathrm{~g}^{-1}$, in the bark of acerola. This element is necessary for the human body since it is part of amino acids such as cysteine and methionine present in hair and nails, being found in the body in concentrations of $140 \mathrm{~g}$ of this element (Lisboa, 2015).

The last element to consider in this work is nitrogen, being a constituent in several components of plants and the sea in the form of amino acids, nucleic acids and chlorophyll, as well as part of numerous microbiological reactions (Novais et al., 2007), In the fruits studied they are stored in the bark of the biribá, whose concentration

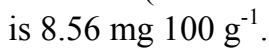

Table 5. Macronutrients analyzed in bark fruit in the northern Amazon

\begin{tabular}{|c|c|c|c|c|c|c|c|}
\hline \multirow[b]{2}{*}{ Fruit } & \multicolumn{7}{|c|}{ Macronutrients } \\
\hline & $\begin{array}{l}\text { Calcium } \\
(\mathrm{Ca})\end{array}$ & $\begin{array}{l}\text { Magnesium } \\
(\mathrm{Mg})\end{array}$ & $\begin{array}{l}\text { Phosphorous } \\
\text { (P) }\end{array}$ & $\begin{array}{l}\text { Potassium } \\
(\mathrm{K})\end{array}$ & $\begin{array}{l}\text { Sodium } \\
(\mathrm{Na})\end{array}$ & $\begin{array}{l}\text { Sulfur } \\
\text { (S) }\end{array}$ & $\begin{array}{l}\text { Nitrogen } \\
(\mathrm{N})\end{array}$ \\
\hline & \multicolumn{6}{|c|}{ 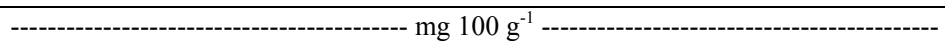 } & ----- \% ------ \\
\hline Abiu (Pouteria caimito) & $22.11 \pm 0.14$ & $13.21 \pm 0.15$ & $4.31 \pm 0.11$ & $242.11 \pm 0.14$ & $0.36 \pm 0.02$ & $15.44 \pm 0.12$ & $0.07 \pm 0.02$ \\
\hline Acerola (Malpighia emarginata) & $27.12 \pm 0.13$ & $37.21 \pm 0.05$ & $7.21 \pm 0.11$ & $121.33 \pm 0.22$ & $17.81 \pm 0.04$ & $37.22 \pm 0.14$ & $6.96 .10^{-3} \pm 0.00$ \\
\hline Araçá (Psidium cattleianum) & $27.23 \pm 0.01$ & $15.27 \pm 0.11$ & $43.47 \pm 0.04$ & $123.11 \pm 0.07$ & $6.83 \pm 0.11$ & $7.31 \pm 0.02$ & $0.07 \pm 0.02$ \\
\hline $\begin{array}{l}\text { Bacupari (Rheedia gardneriana } \\
\text { Planch \& Triana) }\end{array}$ & $44.12 \pm 0.10$ & $35.55 \pm 0.12$ & $6.21 \pm 0.09$ & $411.08 \pm 0.07$ & $7.13 \pm 0.01$ & $3.14 \pm 0.08$ & $0.06 \pm 0.01$ \\
\hline Biribá (Rollinia mucosa) & $47.91 \pm 0.12$ & $64.21 \pm 0.11$ & $20.22 \pm 0.01$ & $441.12 \pm 0.12$ & $17.13 \pm 0,31$ & $19.14 \pm 0.14$ & $8.56 \pm 0.02$ \\
\hline $\begin{array}{l}\text { Camu-camu (Myrciaria dúbia } \\
\text { (Kunth) Mc Vaugh) }\end{array}$ & $52.21 \pm 0.13$ & $32.12 \pm 0.09$ & $17.30 \pm 0.12$ & $431.21 \pm 0.17$ & $18.26 \pm 0.11$ & $27.78 \pm 0.13$ & $0.21 \pm 0.04$ \\
\hline Fruta-do-conde (Annona squamosa) & $50.11 \pm 0.04$ & $28.07 \pm 0.12$ & $15.11 \pm 0.01$ & $417.09 \pm 0.11$ & $3.48 \pm 0.07$ & $23.12 \pm 0.09$ & $0.02 \pm 0.00$ \\
\hline Graviola (Annona muricata) & $33.12 \pm 0.04$ & $21.08 \pm 0.09$ & $16.11 \pm 0.21$ & $521.04 \pm 0.15$ & $2.16 \pm 0.08$ & $13.11 \pm 0.05$ & $0.03 \pm 0.00$ \\
\hline Taperebá (Spondias mombin L.) & $45.21 \pm 0.02$ & $28.11 \pm 0.04$ & $16.22 \pm 0.08$ & $111.34 \pm 0.04$ & $6.56 \pm 0.07$ & $3.21 \pm 0.03$ & $0.02 \pm 0.00$ \\
\hline
\end{tabular}

Note. Analyzes performed in triplicate and using as a standard deviation the value of the t-student for $95 \%$.

Table 6. Micronutrients analyzed in bark fruits in the northern Amazon

\begin{tabular}{|c|c|c|c|c|c|c|c|}
\hline Fruit & $\begin{array}{l}\text { Iron } \\
(\mathrm{Fe})\end{array}$ & $\begin{array}{l}\text { Zinc } \\
(\mathrm{Zn})\end{array}$ & $\begin{array}{l}\text { Manganese } \\
(\mathrm{Mn})\end{array}$ & $\begin{array}{l}\text { Copper } \\
(\mathrm{Cu})\end{array}$ & $\begin{array}{l}\text { Aluminum } \\
\text { (Al) }\end{array}$ & $\begin{array}{l}\text { Boron } \\
\text { (B) }\end{array}$ & $\begin{array}{l}\text { Cobalt } \\
(\mathrm{Co})\end{array}$ \\
\hline & \multicolumn{7}{|c|}{ - $100 \mathrm{~g}^{-1}$} \\
\hline Abiu (Pouteria caimito) & $0.07 \pm 0.00$ & $3.04 \pm 0.01$ & $6.84 \pm 0.11$ & $1.24 \pm 0.05$ & $0.08 \pm 0.01$ & $0.74 \pm 0.03$ & N.D. \\
\hline Acerola (Malpighia emarginata) & $0.44 \pm 0.02$ & $0.04 \pm 0.01$ & $0.78 \pm 0.07$ & $0.09 \pm 0.02$ & $0.16 \pm 0.04$ & $0.22 \pm 0.04$ & N.D. \\
\hline Araçá (Psidium cattleianum) & $4.41 \pm 0.03$ & $12.23 \pm 0.02$ & $0.31 \pm 0.03$ & $3.38 \pm 0.02$ & $0.03 \pm 0.00$ & $0.19 \pm 0.01$ & N.D. \\
\hline $\begin{array}{l}\text { Bacupari (Rheedia gardneriana } \\
\text { Planch \& Triana) }\end{array}$ & $0.32 \pm 0.04$ & $2.94 \pm 0.09$ & $0.50 \pm 0.07$ & $0.82 \pm 0.06$ & $0.22 \pm 0.04$ & $0.12 \pm 0.03$ & $0.031 \pm 0,006$ \\
\hline Biribá (Rollinia mucosa) & $1.32 \pm 0,12$ & $0.94 \pm 0.09$ & $0.57 \pm 0.07$ & $0.87 \pm 0.06$ & $0.27 \pm 0.04$ & $0.22 \pm 0.04$ & $0.011 \pm 0,006$ \\
\hline $\begin{array}{l}\text { Camu-camu (Myrciaria dúbia } \\
\text { (Kunth) Mc Vaugh, Myrtaceae }\end{array}$ & $0.21 \pm 0.08$ & $0.71 \pm 0.03$ & $1.07 \pm 0.07$ & $0.72 \pm 0.02$ & $0.04 \pm 0.01$ & $0.23 \pm 0.02$ & $0.061 \pm 0.002$ \\
\hline Fruta-do-conde (Annona squamosa) & $0.23 \pm 0.07$ & $0.19 \pm 0.01$ & $2.55 \pm 0.01$ & $2.48 \pm 0.04$ & $0.18 \pm 0.03$ & $0.29 \pm 0.17$ & N.D. \\
\hline Graviola (Annona muricata) & $0.81 \pm 0.04$ & $0.32 \pm 0.01$ & $0,64 \pm 0.05$ & $0.39 \pm 0.02$ & $0.38 \pm 0.01$ & $0.37 \pm 0.03$ & $0.010 \pm 0.001$ \\
\hline Taperebá (Spondias mombin L.) & $0.45 \pm 0.08$ & $0.07 \pm 0.01$ & $0.87 \pm 0,05$ & $1.03 \pm 0.07$ & $0.14 \pm 0.02$ & $0.79 \pm 0.06$ & N.D. \\
\hline
\end{tabular}

Note. N.D. not detected. Analyzes performed in triplicate and using as a standard deviation the value of the $\mathrm{t}$-student for $95 \%$. 
Analyzes of microminerals in Amazonian fruit barks are scarce or nonexistent. In Table 6, the values of micronutrient concentrations for the nine fruits studied are presented.

Zinc is one of the important micronutrients since among other functions it is present in the liver mobilization of vitamin A, sexual maturation, fertility and reproduction as well as participating in more than 300 metalloenzymes (Manganaro, 2008; Cominetti, 2009) being found in low concentrations in the fruits studied with the exception of araçá where the concentration of this element in the bark is $12.23 \mathrm{mg} 100 \mathrm{~g}^{-1}$ followed by abiu bark with $\mathrm{Zn}$ concentrations of $3.04 \mathrm{mg} 100 \mathrm{~g}^{-1}$ and the lowest concentrations of This element was obtained in the barks of acerola with concentrations of $0.04 \mathrm{mg} 100 \mathrm{~g}^{-1}$. Studies conducted by Berto et al. (2015) on barks of different Amazonian fruits obtain values of concentration of $\mathrm{Zn}$ for the skin of the biribá of $1.04 \mathrm{mg} 100 \mathrm{~g}^{-1}$ being a value practically similar to that obtained in this work. The recommendations of this element according to the DRI (2001) for adulthood are of $9.4 \mathrm{mg} \mathrm{dia}^{-1}$ for men and $11 \mathrm{mg} \mathrm{dia}^{-1}$ for women.

Another of the micronutrients found in the highest concentration in some fruits is the Mn, being the barks of the

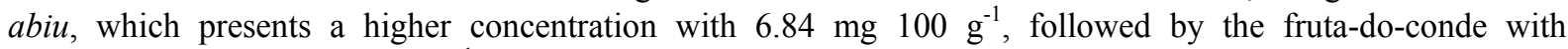
concentrations of $2.55 \mathrm{mg} 100 \mathrm{~g} \mathrm{~g}^{-1}$. This mineral presents lower concentrations for the araçá barks with only 0.31 $\mathrm{mg} 100 \mathrm{~g}^{-1}$. Berto et al. (2015) studied micronutrients in the barks of different Amazonian fruits, obtaining for the biribá concentrations of $0.47 \mathrm{mg} 100 \mathrm{~g} \mathrm{~g}^{-1}$, close to the concentration determined in this work (Table 6). For the taperebá, Sena et al. (2014), study the composition of micronutrients in flour obtained from residues of fruit

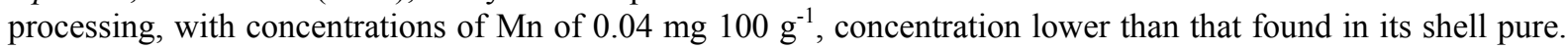
This element is interesting for its implication with diverse metabolic reactions in the organisms of immune response, synthesis of ATP and as cofactor in metalloenzymes (Burton \& Guillarte, 2009) being the recommendations of this element for adults of $2.3 \mathrm{mg} \mathrm{dia}^{-1}$ for men and $1.8 \mathrm{mg} \mathrm{dia}^{-1}$ for women (DRI, 2001).

Iron is another essential micronutrient whose recommendations according to DRI (2001) for adults are $8 \mathrm{mg} \mathrm{dia}^{-1}$ and from the age of fifty, these amounts are reduced to $8 \mathrm{mg} \mathrm{dia}^{-1}$ being found in the human body at concentrations of 3-5 grams (Fantisi et al., 2008). As with Zn, it is the araçá that has a higher concentration in the barks of fruits studied whose values are $12.23 \mathrm{mg} 100 \mathrm{~g}^{-1}$, being the concentration of this element excessively low in the abiu shell whose concentration is of $0.07 \mathrm{mg} 100 \mathrm{~g}^{-1}$.

Copper is another microelement of interest in the bark of the fruits studied, being found in a higher concentration in the araçá bark with a value of $3.38 \mathrm{mg} 100 \mathrm{~g}^{-1}$ and in a lower concentration in the bark of acerola with a concentration of $0.09 \mathrm{mg} 100 \mathrm{~g}^{-1}$. The deficiency of this element, has important series implications for the organism as is the case of the diseases of Wilson and Menkes (Amancio, 2017) being the recommendations of $\mathrm{Cu}$ in adulthood according to the DRI (2011) of $700 \mu \mathrm{g} \mathrm{day}^{-1}$.

Boron is another essential element for man, related to maintaining the integrity of the plasma membrane and involved with bone metabolism (Brown et al., 2002). According to the DRI (2001), the recommendations of B for adults are of $20 \mathrm{mg} \mathrm{dia}^{-1}$. The highest concentrations of B found in the fruit bark studied in this study are in the bark of taperebá whose concentration is $0.79 \mathrm{mg} 100 \mathrm{~g}^{-1}$ and for abiu with concentrations of $0.74 \mathrm{mg} 100 \mathrm{~g}^{-1}$. The lowest concentrations of this element are in the bacupari barks whose concentration is of $0.12 \mathrm{mg} 100 \mathrm{~g} \mathrm{~g}^{-1}$. Ribeiro et al. (2016) studied the concentrations of B in dry сати-сати fruits and obtained values of $1.7-1.8 \mathrm{mg} 100 \mathrm{~g} \mathrm{~g}^{-1}$, values higher than only for the isolated skin (Table 6).

The Cobalt is the element found in ultra-trace concentrations in the barks of the studied fruits, being only detected in bacuparí, biribá, camu-camu and graviola whose values oscillate between $10 \mu \mathrm{g} 100 \mathrm{~g}^{-1}$ for the skin of the graviola being the highest concentration of this element in the bark of camu-camu in concentration of $61 \mu \mathrm{g} 100$ $\mathrm{g}^{-1}$. These values are lower than those recommended by FAO/WHO, which should be ingested $0.58 \mathrm{mg} \mathrm{kg}^{-1}$ as a function of the individual's body size (FAO, 2013). This element in higher concentrations can cause toxicity as is the case of cardiomyopathy, as well as linked to other nervous and blood clotting problems (Seghizzi et al., 1994).

Finally, the aluminum was also identified in the fruit skin studied, being one of the metals that must be found in low concentrations in foods since this metal being a neurotoxic substance, is involved with Alzehimer's disease (Armstrong, 2002). The concentrations of $\mathrm{Al}$ in this work are low, being the highest value for the graviola bark with $\mathrm{Al}$ concentration of $0.38 \mathrm{mg} 100 \mathrm{~g}^{-1}$ and the lowest concentration of Al for сати-сати bark with concentration of $0.03 \mathrm{mg} 100 \mathrm{~g}^{-1}$.

\subsection{Statistic Analysis}

\subsubsection{Pearson Correlation Coefficient}

Table 7 presents the Pearson correlation matrix between the different elements for the bark of the different fruits. 
Table 7. Pearson correlation matrix between the different elements for the bark of Amazonian fruits

\begin{tabular}{|c|c|c|c|c|c|c|c|c|c|c|c|c|c|c|}
\hline & $\mathrm{Ca}$ & Mg & $\mathbf{P}$ & $\mathbf{K}$ & $\mathbf{S}$ & $\mathbf{N}$ & $\mathrm{Fe}$ & $\mathbf{Z n}$ & Mn & $\mathrm{Cu}$ & $\mathrm{Na}$ & Al & B & Co \\
\hline $\mathrm{Ca}$ & 1 & & & & & & & & & & & & & \\
\hline Mg & $0.66^{*}$ & 1 & & & & & & & & & & & & \\
\hline $\mathbf{P}$ & $0.00 \mathrm{~ns}$ & $-0.10 \mathrm{~ns}$ & 1 & & & & & & & & & & & \\
\hline K & $0.55 \mathrm{~ns}$ & $0.41 \mathrm{~ns}$ & $-0.19 \mathrm{~ns}$ & 1 & & & & & & & & & & \\
\hline $\mathbf{S}$ & $0.05 \mathrm{~ns}$ & $0.38 \mathrm{~ns}$ & $-0.25 \mathrm{~ns}$ & $0.09 \mathrm{~ns}$ & 1 & & & & & & & & & \\
\hline $\mathbf{N}$ & $0.39 \mathrm{~ns}$ & $0.82 * *$ & $0.14 \mathrm{~ns}$ & $0.36 \mathrm{~ns}$ & $0.17 \mathrm{~ns}$ & 1 & & & & & & & & \\
\hline $\mathrm{Fe}$ & $-0.10 \mathrm{~ns}$ & $-0.08 \mathrm{~ns}$ & $0.94 * *$ & $-0.21 \mathrm{~ns}$ & $-0.16 n s$ & $0.11 \mathrm{~ns}$ & 1 & & & & & & & \\
\hline Zn & $-0.26 \mathrm{~ns}$ & $-0.32 \mathrm{~ns}$ & $0.76^{*}$ & $-0.28 \mathrm{~ns}$ & $-0.30 \mathrm{~ns}$ & $-0.12 \mathrm{~ns}$ & $0.89^{* *}$ & 1 & & & & & & \\
\hline Mn & $-0.28 \mathrm{~ns}$ & $-0.38 \mathrm{~ns}$ & $-0.38 \mathrm{~ns}$ & $-0.05 \mathrm{~ns}$ & $0.13 \mathrm{~ns}$ & $-0.19 \mathrm{~ns}$ & $-0.30 \mathrm{~ns}$ & $0.00 \mathrm{~ns}$ & 1 & & & & & \\
\hline $\mathrm{Cu}$ & $0.12 \mathrm{~ns}$ & $-0.29 \mathrm{~ns}$ & $0.73 *$ & $-0.13 \mathrm{~ns}$ & $-0.19 \mathrm{~ns}$ & $-0.12 \mathrm{~ns}$ & $0.69^{*}$ & $0.75^{*}$ & $0.13 \mathrm{~ns}$ & 1 & & & & \\
\hline $\mathrm{Na}$ & $-0.19 \mathrm{~ns}$ & $0.44 \mathrm{~ns}$ & $0.01 \mathrm{~ns}$ & $-0.34 \mathrm{~ns}$ & $0.23 \mathrm{~ns}$ & $0.44 \mathrm{~ns}$ & $-0.01 \mathrm{~ns}$ & $-0.20 \mathrm{~ns}$ & $-0.51 \mathrm{~ns}$ & $-0.38 \mathrm{~ns}$ & 1 & & & \\
\hline Al & $0.00 \mathrm{~ns}$ & $-0.09 \mathrm{~ns}$ & $0.88 * *$ & $0.00 \mathrm{~ns}$ & $-0.14 n s$ & $0.02 \mathrm{~ns}$ & $0.96 * *$ & $0.85^{* *}$ & $-0.33 \mathrm{~ns}$ & $0.65^{*}$ & $-0.19 \mathrm{~ns}$ & 1 & & \\
\hline B & $-0.03 \mathrm{~ns}$ & $-0.30 \mathrm{~ns}$ & $-0.25 \mathrm{~ns}$ & $-0.24 n s$ & $-0.16 \mathrm{~ns}$ & $-0.20 \mathrm{~ns}$ & $-0.31 \mathrm{~ns}$ & $-0.22 \mathrm{~ns}$ & $0.58 \mathrm{~ns}$ & $-0.08 \mathrm{~ns}$ & $-0.49 \mathrm{~ns}$ & $-0.34 n s$ & 1 & \\
\hline Co & $-0.36 \mathrm{~ns}$ & $-0.17 \mathrm{~ns}$ & $-0.18 \mathrm{~ns}$ & $-0.06 \mathrm{~ns}$ & $-0.49 \mathrm{~ns}$ & $-0.03 \mathrm{~ns}$ & $-0.26 \mathrm{~ns}$ & $-0.17 \mathrm{~ns}$ & $-0.26 \mathrm{~ns}$ & $-0.32 \mathrm{~ns}$ & $0.46 \mathrm{~ns}$ & $-0.32 \mathrm{~ns}$ & $-0.39 \mathrm{~ns}$ & 1 \\
\hline
\end{tabular}

Note. ns (not significant) $\mathrm{p}>0.05,{ }^{*} \mathrm{p}<0.05, * * \mathrm{p}<0.01$.

Table 7 presents the Pearson interaction values for the different fruit constituents in the bark of the fruit, where highly significant interactions are found at a significance level of $1 \%$ for nitrogen systems with magnesium $(0.82)$, aluminum with phosphorus $(0.88)$, iron with phosphorus $(0.94)$, aluminum with iron $(0.96)$, zinc with iron $(0.89)$ and aluminum with zinc $(0.85)$. On the other hand, there are significant interactions at the significance level of $5 \%$ for the magnesium systems with calcium (0.66), zinc with phosphorus $(0.76)$, copper with phosphorus $(0.73)$, copper with iron $(0,69)$, copper with zinc $(0.75)$ and aluminum with copper $(0.65)$. For the remaining elements there is no significant interaction.

\subsubsection{Principal Component Analysis (PCA)}

The analyzes of main components were carried out jointly for the evaluated systems (abiu, bacupari, acerola, graviola, camu-camu, araçá, biribá and taperebá), independently for bark of the fruit, in order to find a new set of variables (main components), uncorrelated, that explain the structure of the variation, being represented the weight of each variable analyzed in each component (axes).

In the blipot (Figure 1), the results of the analysis of the main components (PCA) for the bark of the different fruits are represented, being explained the $56.0 \%$ of the original variability of the data retained in these components. These results indicate that CP1 allowed to distinguish the fruits that are associated to the minerals in the barks, being the fruits biribá, fruta-do-conde, camu-camu and araçá who were associated.

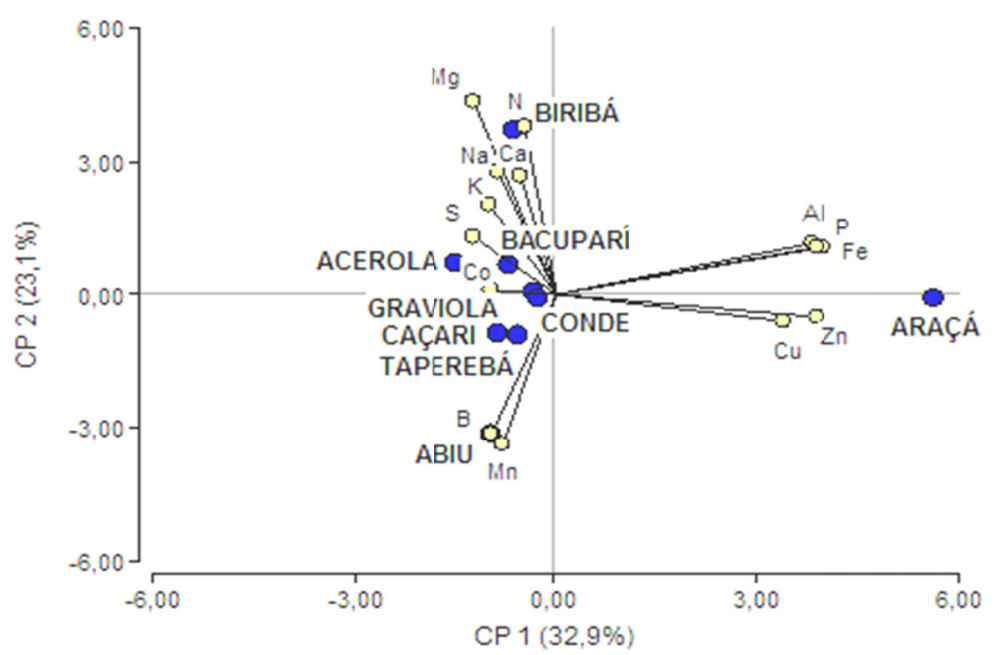

Figure 1. Distribution of the original variables among the different fruits for the barks on the first and second main component (CP1 and $\mathrm{CP} 2)$ 
The arrangement of the sequence in Figure 1, shows that the systems can be grouped into two sets, the first major component (CP1), contributed $32.9 \%$ of the total variance explained, however most of the minerals that were strongly affected, between $(\mathrm{P})$, iron $(\mathrm{Fe})$, zinc $(\mathrm{Zn})$ and copper $(\mathrm{Cu})$ contributing positively to $\mathrm{CP} 1$ and inverse with elements nitrogen $(\mathrm{N})$, magnesium $(\mathrm{Mg})$, calcium $(\mathrm{Ca})$, sodium $(\mathrm{Na})$, potassium $(\mathrm{K})$, sulfur $(\mathrm{S})$, cobalt (Co), boron (B) and manganese (Mn).

These results indicate that $\mathrm{CP} 1$ allowed to distinguish the fruits that are associated to the minerals in the part of the bark, being only the araçá who is associated with these minerals.

The second major component (CP2) accounted for $23.1 \%$ of the total data, nitrogen $(\mathrm{N})$, magnesium $(\mathrm{Mg})$, calcium $(\mathrm{Ca})$, sodium $(\mathrm{Na})$, potassium $(\mathrm{K})$, sulfur $(\mathrm{S})$, cobalt $(\mathrm{Co})$, boron $(\mathrm{B})$ and manganese $(\mathrm{Mn})$.

\subsubsection{Hierarchical Grouping Analysis (HCA)}

Through the HCA, data can be displayed in a two-dimensional space in order to emphasize their natural groupings and patterns, relating the samples so that the most similar are related to each other, presenting the samples in dendogram, grouping the samples and variables according to with its similarity.

In Figure 2 the dendogram for the HCA analyzes of the different fruit bark studied is presented.

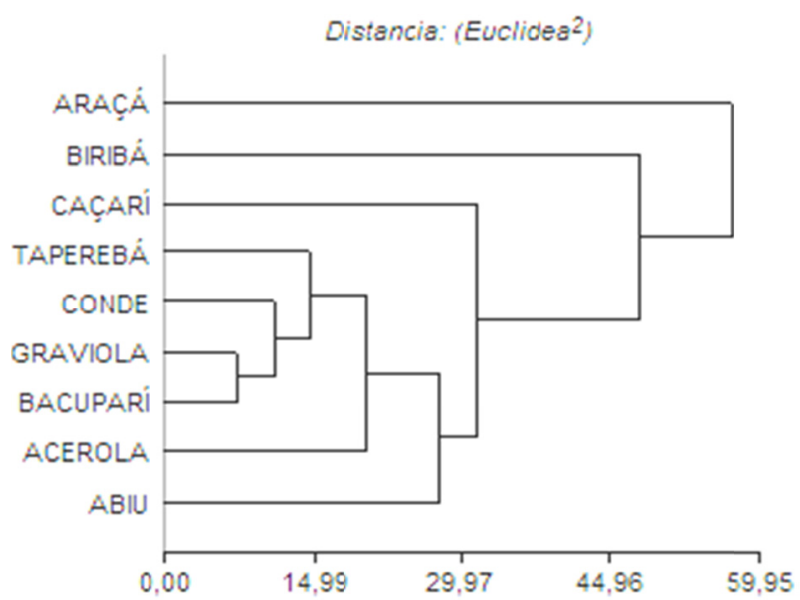

Figure 2. Dendogram by HCA, Euclidean distance and incremental connection technique for the minerals present in the fruit bark studied

For the production of tested fruits, the trends observed through or analysis of principal components, observed through HCA, observing that either taperebá, fruta-do-conde, graviola, bacupari and abiu are not grouped between them, and for distance. 29.98, sendo or value of metada gives maximum distance, or araçá e biribá separated rest.

\section{Conclusions}

Given the values obtained from nutritional intake and minerals for the barks of the fruits studied, which in some cases are superior to those of the edible parts, the husks could be used as an alternative source of nutrients, thus avoiding the waste of food, taking advantage of the source of nutrients and at the same time, other products can be prepared from these samples such as jellies, sweets and flours.

\section{Acknowledgements}

To the Research Center and post-graduation in Science and Technology (NPPGCT) of the Federal University of Roraima, especially to the researchers of the OLEOQUÍMICOS group, to the nucleus of research in Agriculture (NUPAGRI) of the Campus of Cauamé UFRR for being able to carry out the experimental work in these laboratories and to CAPES for the scholarship.

\section{References}

Ajila, C. M., Bhat, S. G., \& Prasada Rao, U. J. S. (2007). Valuble componentes of raw and ripe peels from two Indian mango varieties. Food Chemistry, 102, 1006-1011. https://doi.org/10.1016/j.foodchem.2006.06.036 
Almeida, M. M. A., de Souza, P. H. M., Fonseca, M. L., Magalhães, C. E. C., Lopes, M. F. G., \& de Lemos, T. L. G. (2009). Evaluation of macro and micro-mineral content in fruits cultivated in the northeast of Brazil. Ciência e Tecnologia de Alimentos, 23, 581-589. https://doi.org/10.1590/S0101-20612009000300020

Amancio, O. M. S. (2017). Funções plenamente reconhecidas de nutrients cobre. Série de publicações ILSI Brasil (p. 28).

Andrade, J. S., Aragão, C. G., \& Ferreira, S. N. (1993). Caracterização física e química dos frutos de araçá-pera (Psidium acutangulum D.C.). Acta Amazônica, 23, 213-217. https://doi.org/10.1590/1809-43921993233217

Armstrong, T. A., Flowers, J. W., Spears, J. W., \& Nielsent, F. H. (2002). Long-term effects of boron supplementation on reproductive characteristics and bone mechanical properties in gilts. J. Anim Sci, 80(1), 154-161. https://doi.org/10.2527/2002.801154x

Berto, A., da Silva, A. F., Visentainer, J. V., Matsushita, M., \& de Souza, N. E. (2015). Proximate composition, mineral contentes and fatty acid compositions of native Amazonian fruits. Food Research International, 77, 441-449. https://doi.org/10.1016/j.foodres.2015.08.018

Bomfim, M. P., Dias, N. O., Bôas-Souza, I. V., São José, A. R., \& Pires, M. M. (2014). Produção, características físico-químicas da pinha (Annona squamosa L.) em função do número de frutos por planta. Rev. Iber. Tecnologia Postcosecha, 15, 1-6.

Bramont, W. B., Leal, I. L., Umsza-Guez, M. A., Guedes, A. S., Alves, S. C. O., Reis, J. H. O., Barbosa, J. D. V., \& Machado, B. A. S. (2018). Comparison of the centesimal, mineral and phytochemical composition of pulps and peel of tem diferentes fruits. Revista Virtual de Química, 10, 811-823. https://doi.org/10.21577/ 1984-6835.20180059

Brown, P. H., Bellaloui, N., \& Wimmer, M. (2002). Boron in plant biology. Plant Biol, 4, 205-223. https://doi.org/10.1055/s-2002-25740

Burton, N. C., \& Guilarte, T. R. (2009). Manganese neurotoxicity: Lessons learned from longitudinal studies in nonhuman primates. Environ Health Perspect, 117, 325-332. https://doi.org/10.1289/ehp.0800035

Canuto, G. A. B., Xavier, A. A. O., Neves, L. C., \& Benassi, M. T. (2010). Caracterização físico química de polpas de frutos da Amazônia e sua correlação com anti-radical livre. Rev. Bras. Frutic., 32, 1196-1205. https://doi.org/10.1590/S0100-29452010005000122

Carlone, A. L. S., Shigueoka, K. S., Gomes, R. G., Garcia, E. E., \& Nogami, E. M. (2016). XXVEAIC VEAIC, $2^{\circ}$ Encontro de Iniciação Científica.

Chitarra, M. I. F., \& Chitarra, A. B. (2005). Pós-colheita de frutos e hortaliças: Fisiologia e manuseio (p. 320). Lavras: ESAL/FAEPE.

Cominetti, C., \& Cozzolino, S. M. F. (2010). Funções plenamente reconhecidas de nutrientes Zinco. Série de publicações ILSI Brasil (p. 20).

Correia, R. T. P., Mccue, P., Magalhães, M. M. A., Macêdo, G. R., \& Shetty, K. (2004). Phenolic antioxidante enrichment of soy flour-supplemented guava waste by Rhizopus oligosporus-mediated solid-state bioprocessing. Journal of Biochemistry, 28, 404-418. https://doi.org/10.1111/j.1745-4514.2004.05703.x

Cuppari, L., \& Bazanelli, A. P. (2010). Funções plenamente reconhecidas de nutrientes potássio. Série de Publicações ILSI Brasil: São Paulo (p. 16).

DRI (Dietary Reference Intakes). (2001). Retrieved from https://www.nal.usda.gov/fnic/dietary-reference-intakes

Elcinto, M. A. (2000). El potássio para su salud. Medicina naturista, 1, 17-19.

EMBRAPA (Empresa Brasileira de Pesquisa Agropecuária). (2009). Manual of chemical analyzes of soils, plants and fertilizers (2nd ed.). Brasilia, DF.

Epstein, E., \& Bloom, A. J. (2006). Nutrição mineral de plantas: principios e perspectivas (p. 401). Londrina, Brazil.

Fantisi, A. P., Canniatti-Brazaca, S. G., Souza, M. C., \& Mansi, D. N. (2008). Iron availability in food mixtures including foods with high vitamin $\mathrm{C}$ and cysteine contentes. Ciência e Tecnologia de Alimentos, 28, 435-439. https://doi.org/10.1590/S0101-20612008000200026

FAO/WHO. (2013). Joint FAO/WHO Expert committee on food additives. Summary and conclusions in 53rd meeting, Rome 10-19 June. 
Fernández, L., Soria, M., Sánchez, G., Pérez Almandoz, C. J., Marchese L., Troncoso, J., ... Pérez, A. (2006). Clarificación de jugo de manzana con membranas inorgánicas no comerciales. Laboratorio de Desarrollo-Jugos del Sur S.A y LACPSUM, Universidad Nacional de San Luis, Argentina; Universidad Nacional del Comahue, Argentina; Buenos Aires 1400-8300-Neuquén-Argentina CONICYT (Comisión Nacional de Investigación Científica y Tecnológica).

Freitas, B. S. M. (2017). Caracterização e qualidade física e química dos frutos e secagem por leito de espuma da polpa de cajá (Spondias mombin L.). Instituto Federal de Educação, Ciência e Tecnologia Goiano, Campus Rio Verde.

Godim, J. A., Moura, M. F. V., Dantas, A. S., Medeiros, R. L. S. \& Santos, K. M. (2005). Composição centesimal e de minerais em cascas de frutas. Ciênc. Tecnol. Aliment, 25, 825-827. https://doi.org/10.1590/S0101-2061 2005000400032

Godoy, R. C. B., Matos, E. L. S., Amorin, T. S., Neto, M. A. S., Ritzinger, R., \& Waszczynsky, J. N. (2008). Avaliação de genótipos e variedades de acerola para consumo in natura e para elaboração de doces. $B$. Ceppa, 26, 197-201. https://doi.org/10.5380/cep.v26i2.13274

IAL (Instituto Adolfo Lutz). (2008). Physicochemical methods for food analysis (IV ed.). São Paulo, Brazil.

Johnston, J. W., Hewett, E. W., \& Hertog, M. L. (2002). Postharvest soffening of apple (Malus domestica) fruit: a review. Crop Hortic Sci, 30, 145-160. https://doi.org/10.1080/01140671.2002.9514210

Lisboa, W. (2015). Ciclo do enxofre-bacterias sulfitogenica.

Maeda, R. N., Pantoja, L., Yuyama, L. K. O., \& Chaar, J. M. (2006). Determinação da formulação e caracterização do néctar de camu-camu (Myrciaria dúbia McVaugh). Ciênc. Tecnol. Aliment, 26, 70-74. https://doi.org/10.1590/S0101-20612006000100012

Maia, G. A., Sousa, P. H. M., \& Lima, A. S. (2007). Processamento de sucos de frutas tropicais. Fortaleza: UFC.

Manganaro, M. M. (2008). Nutrição aplicada à enfermagem. In G. F. Murta (Ed.), Saberes e práticas: Guia para ensino e aprendizado de enfermagem (Vol. 3, p. 456). São Caetano do Sul: Difussão.

Melo, P. C. T., \& Vilela, N. J. (2005). Desafios e perspectivas para a cadeia brasileira de tomate para processamento industrial. Horticultura Brasileira, 23, 154-157. https://doi.org/10.1590/S0102-05362005 000100032

Mendes-Filho, N. E., Carvalho, M. P., \& de Souza, J. M. T. (2014). Determination of macronutrients and minerals nutriente of the mango pulp (Mangifera indica L.). Perspectivas da Ciência e Tecnologia, 6, 22-36.

Monteiro, T. H., \& Vannucchi, H. (2014). Funções plenamente reconhecidas de nutrientes Magnésio. Série de Publicações ILSI Brasil: São Paulo (p. 20).

Montero, I. F., Chagas, E. A., Melo Filho, A. A., Saravia Maldonado, S. A., Carvalho, R. S., Duarte, E. D. R. S., \& Chagas, P. C. (2018). Evaluation of total phenolic compounds and antioxidant activity in Amazon Fruit. Chemical Engineering Transactions, 64, 649-654.

Novais, R. F., Alvarez, V. H., Barros, N. F., Fontes, R. L. F., Cantarutti, R. B., \& Neves, J. C. L. (2007). Fertilidade do Solo (1st ed., p. 1017). Sociedade Brasileira de Ciência do Solo, Minas Gerais.

Poovaiah, B., Glenn, G., \& Reddy, A. (1988). Calcium and fruit softening: Physiology and biochemistry. Hortic. Rev, 10, 107-152. https://doi.org/10.1002/9781118060834.ch4

Ribeiro, P. F., Stringheta, P. C., Oliveira, E. B., Mendoça, A. C., \& Sant'Ana, H. M. P. (2016). Levels of vitamin C, $\beta$-carotene and minerais in camu-camu cultivated in different environments. Cienc. Rural, 46, 567-562. https://doi.org/10.1590/0103-8478cr20150024

Rienzo, J. A. D., Casanoves, F., Balzarini, M. G., Gonzales, L., Tablada, M., \& Robledo, C. W. (2016). InfoStat Release 2016. InfoStat Group FCA, Universidad Nacional de Córdoba, Argentina. Retrieved from http://www.infoestar.com.ar

Rubilar, M., Pinelo, M., Shene, C., Sineiro, J., Nuñez, M. J. (2007). Separation and HPLC-MS identification of phenolic antioxidants from agricultural resíduos almond hulls and grape pomace. Journal of Agricultural and Foods Chemistry, 55, 10101-10109. https://doi.org/10.1021/jf0721996 
Sacramento, C. K., Faria, J. C., da Cruz, F. L., Barretto, W. S., Gaspar, J. W., \& Leite, J. B. V. (2003). Physical-chemical characterization of fruit of three types of soursop trees (Annona muricata L.). Ver. Bras. Frutic., 25(2), 329-331. https://doi.org/10.1590/S0100-29452003000200037

Santos, M. S. (2005). Cervejas e refrigerantes. Companhia de Tecnologia de Saneamento Ambiental (p. 58). São Paulo: CETESB.

Seghizzi, P., D’Adda, F., Borleri, D., Barbic, F., \& Mosconi, G. (1994). Cobalt myocardipathy: A critical review of literature. Sci Total Environ, 150, 105-109. https://doi.org/10.1016/0048-9697(94)90135-X

Sena, D. N., Almeida, M. M. B., Sousa, P. H. M., Fernandes, M. F. L., \& Magalhães, C. E. C. (2014). Microminerais em farinhas de resíduos do processamento de frutas tropicais. XX Congresso Brasileiro de Engenharia Quimica (COBEQ), 19-22 Octubre, 2014. https://doi.org/10.5151/chemeng-cobeq2014-035925862-137144

Silva, A. M., \& da Silva, S. R. B. (2016). XVIII Encontro Nacional de Ensino de Química (XVIII ENEQ), Florianópolis, Brasil, 25-28 de Julho.

Silva, D. I. S. (2015). Estudo da transferência de calor e massa na secagem em leito fixo visando o aproveitamento de resíduo de acerola (Malpighia emarginata DC) (Tese de Doutorado, Programa de Pós-graduação em Engenharia Química. Universidade Federal de Uberlândia, Uberlândia, MG).

\section{Copyrights}

Copyright for this article is retained by the author(s), with first publication rights granted to the journal.

This is an open-access article distributed under the terms and conditions of the Creative Commons Attribution license (http://creativecommons.org/licenses/by/4.0/). 